\title{
МЕЖДУНАРОДНЫЙ СИМПОЗИУМ «НАНОФИЗИКА И НАНОМАТЕРИАЛЫ», ПОСВЯЩЕННЫЙ 105-ЛЕТИЮ СО ДНЯ РОЖДЕНИЯ В. Б. АЛЕСКОВСКОГО
}

\author{
(C) 2018 А. Г. Сырков \\ Санкт-Петербургский горный университет. В.О., 21 линия 2, С.-Петербург, Россия \\ e-mail:nin-org@bk.ru
}

Поступила в редакцию 26.02.2018

DOI: https://doi.org/10.17308/kcmf.2018.20/488

22-23 ноября 2017 г. в Санкт-Петербурге состоялся Международный симпозиум «Нанофизика и Наноматериалы» (НиН-2017 или N\&N-2017). Симпозиум НиН-2017 проведен на базе Санкт-Петербургского горного университета (Горного университета или СПГУ). В работе симпозиума приняли участие 210 специалистов из Великобритании, США, Беларуси, Казахстана, Украины и России.

Международный симпозиум НиН-2017 организован Горным университетом по распоряжению ректора от 29.06.2017 при содействии Минобрнауки России, Международной консалтинговой компании IMC Montan, компании GMC, региональных отделений ЮНЕСКО в России и ООО «МК Констракшн» (Москва).

Цель симпозиума: провести на высоком научном уровне обмен актуальной информацией в области физики, химии, технологии и методов контроля низкоразмерных систем и наноматериалов, востребованных в минерально-сырьевом комплексе, а также обсудить проблемы высшего образования в области нанотехнологий.

Симпозиум НиН-2017 был посвящен памяти члена-корреспондента РАН Валентина Борисовича Алесковского (1912-2006) - создателя и руководителя ведущей в РФ научной школы (НШ 2236.2003.3) в области химии высокоорганизованных веществ. Профессор В. Б. Алесковский (рис. 1)предложил остовную гипотезу твердых веществ (1952). В 1952-2006 гг. выполнил с сотрудниками пионерские исследования в области молекулярного наслаивания и химической сборки наноматериалов $[1,2]$. Разработал концепцию химии надмолекулярных соединений (начало 1990-х годов) и представления о химико-информационном синтезе твердых веществ $[3,4]$.
Сегодня ученики Алесковского работают не только в российских университетах и научных учреждениях, но и за рубежом (США, Германия, Финляндия). О 105-летии со дня рождения В. Б. Алесковского в 2017 г. вспоминали не только в СПбГТИ(ТУ), где он начинал свою научную карьеру и прошел путь от студента до ректора, а также в СПбГУ, где отработал более 30 лет (19752006), и в СПГУ, где трудятся ученики Валентина Борисовича. Эти ученики (Сырков А. Г., Денисова О. В. и др.) уже сами подготовили десяток кандидатов и докторов наук, которые развивают идеи Алесковского в области синтеза и исследования наноструктурированных металлов и проводят Международный симпозиум «Нанофизика и Наноматериалы» $[5,6]$.

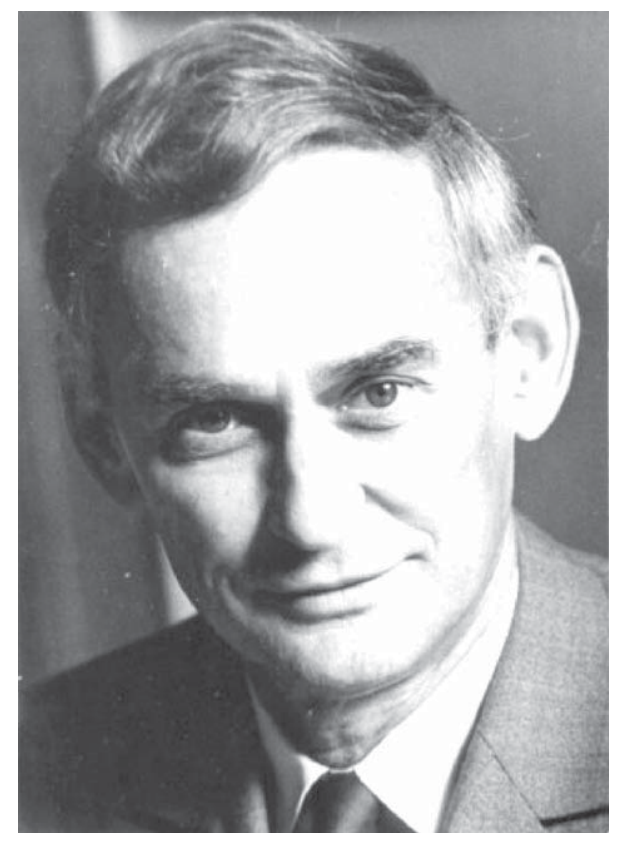

Рис. 1. Алесковский Валентин Борисович 


\section{А. Г. СЫРКОВ}

Помимо названных выше сотрудников СПГУ, в Оргкомитете и рабочей группе симпозиумов НиН-2017 и НиН-2018 работают прямые ученики Алесковского: профессор Ежовский Ю. К. и профессор Пак В. Н., представляющие ответвления научной школы Валентина Брисовича, которые успешно функционируют в СПбГТИ(ТУ) и РГПУ им. А. И. Герцена соответственно. Есть еще одна причина, чтобы не забывать творческое наследие Учителя. Выяснилось (см. материал ниже), что профессор Горного института П. П. Веймарн, стоявший у истоков науки о нанотехнологиях [6], более 100 лет назад развивал схожие представления в области стехиометрии твердых веществ. Учитывая, что Веймарн был учеником другого знаменитого выпускника Горного института - Н. С. Курнакова - в рамках симпозиума НиН-2017 представлялось важным проследить эволюцию взглядов Курнакова, Веймарна и Алесковского на проблемы соединений переменного состава и соблюдения закона постоянства состава твердых химических соединений.

Нам приятно отметить, публикуя данный материал в научном журнале, который издается в Воронежском государственном университете, что обозначенной выше тематикой занимались также ученики Н. С. Курнакова, переехавшие еще в советское время работать на химическом факультете ВГУ (проф. Палкин А. П. и сотр.).

На открытии симпозиума НиН-2017 с приветственным словом к участникам обратился проректор по научной работе, профессор В. Л. Трушко (рис. 2, 3). Он подчеркнул, что в Горном университете работают 17 научных школ, в том числе школа металлургов, у истоков которой стоял академик Н. С. Курнаков. Горный университет занял 15-ое место в Мировом рейтинге университетов горно-технического профиля. Все нанотехнологические разработки защищены патентами, отмечены более чем 35-ю золотыми и серебряными медалями на Международных выставка и конгресcax. Международный симпозиум «Нанофизика и Наноматериалы», ежегодно проводимый в СПГУ, стал традиционным. По материалам симпозиумов 2013-2016 гг. опубликованы 6 выпусков (номеров) рецензируемого научного журнала Smart Nanocomposites и индексированные в базе Scopus две коллективные монографии (издательство Nova SciencePublishers, Inc., Нью-Йорк, США) [7, 8].

С приветствиями и пожеланиями успешной работы к собравшимся также выступили: глава Представительства компании IMC Montan (Beликобритания) И. В. Плескунов (рис. 4), профессор В. Н. Пак (РГПУ им. А. И. Герцена), профес-

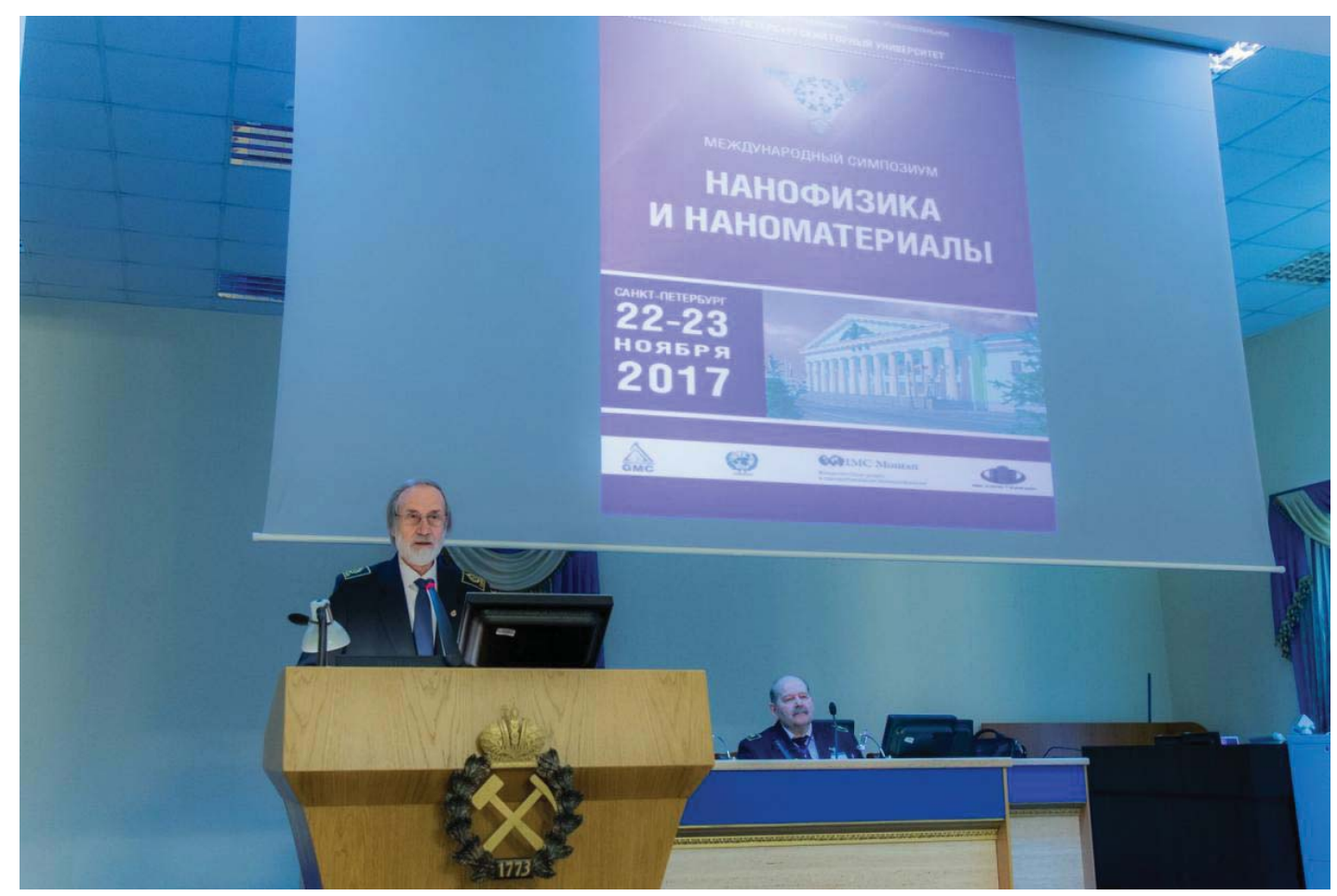

Рис. 2. Приветственное слово проректора по научной работе СПГУ, председателя Оргкомитета к участникам симпозиума НиН-2017 


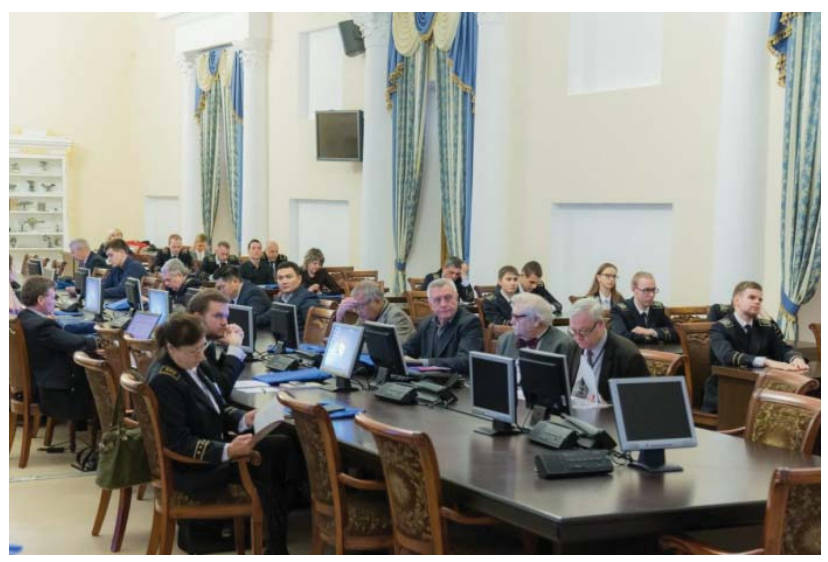

Рис. 3. Начало Пленарного заседания НиН-2017

сор В. В. Носов (СПбПУ, СПГУ), А. С. Мустафаев (СПГУ). Научным руководителем симпозиума профессором А. Г. Сырковым были зачитаны поздравительные письма и адреса, поступившие в Оргкомитет НиН-2017 от Университета г. Кампинас (Бразилия), компании «Славкалий» (Беларусь), Ханойского Открытого Университета (Вьетнам), БГТУ (Беларусь), СПбГУ, СПбГЭТУ «ЛЭТИ», СПбГТИ(ТУ) (Россия).

Профессор, заведующий кафедрой общей и технической физики СПГУ А. С. Мустафаев в своем выступлении отметил, что многим его соавторам по статьям и докладам на НиН-2017 из Принстонского университета Министерство энергетики США в связи с антироссийскими санкциями не рекомендовало ехать в С.-Петербург для участия в симпозиуме. Тем не менее, совместные доклады представлены, работы по плазменным нанотехнологиям и физике плазмы продолжаются.Для

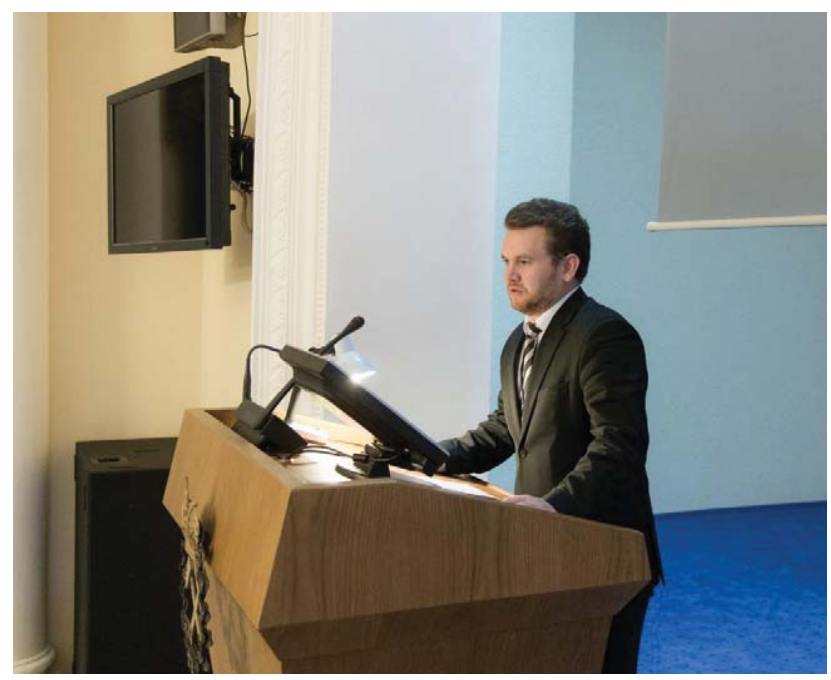

Рис. 4. Выступает И. В. Плескунов (IMC Montan, Великобритания) проведения совместных исследований сам Мустафаев А. С. каждый месяц ездит в Принстонский и другие университеты США.

Профессор В. Н. Пак, приветствуя участников НиН-2017 (рис. 5), вспомнил о годах работы под руководством В. Б. Алесковского в связи со 105летием со дня его рождения.

По мнению Пака В. Н., Алесковский умел в общении со своими учениками, произнеся совсем немного слов, дать заряд для успешной научной работы на всю жизнь.

Несомненно, В. Б. Алесковский был неординарным ученым и притягательной личностью. После окончания с отличием в 1937 г. ЛТИ им. Ленсовета он в 1940 г. успешно защищает кандидатскую диссертацию. В 1941 г. уходит на фронт, назначается начальником химической службы полка, с ранениями и наградами проходит всю Великую Отечественную войну (рис. 6, 7), участвуя во многих известных боевых операциях в России и за пределами СССР. После окончания войны возвращается в Технологический институт и устраивается на работу по одним данным (Википедия) ассистентом кафедры физической химии, по другим (Музей Технологического института, СПб) - на кафедру сорбционной техники (рис. 8). Получает Сталинскую стипендию для написания докторской диссертации «Остовная гипотеза и опыт приготовления активных твердых тел» и в 1952 г. успешно защищает её. В 1967-1975 гг. - ректор ЛТИ им. Ленсовета (рис. 9), в 1975 г. назначен ректором ЛГУ им. А. А. Жданова, где работает (рис. 10-12) до последних дней.

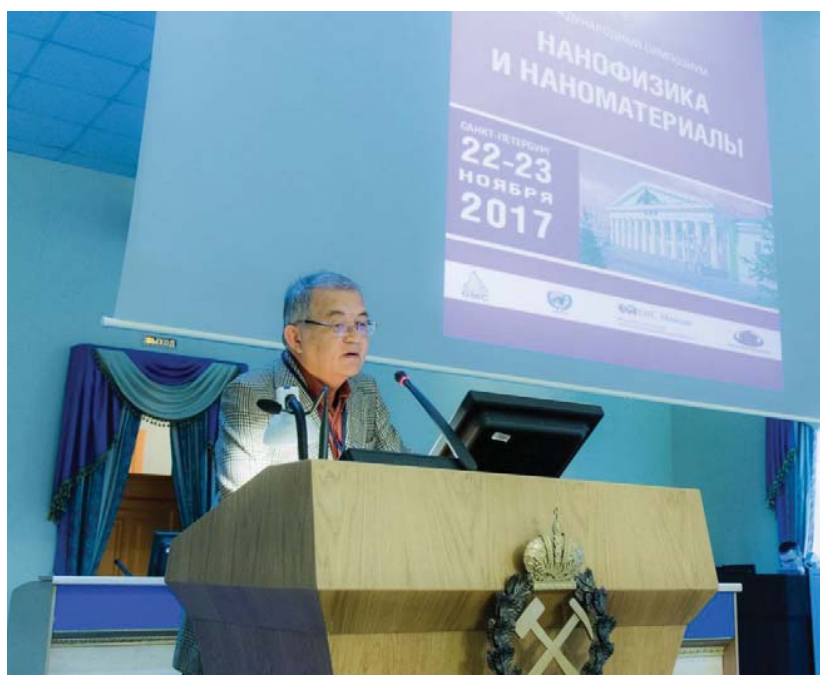

Рис. 5. Приветственное слово В. Н. Пака (Россия) 


\section{А. Г. СЫРКОВ}

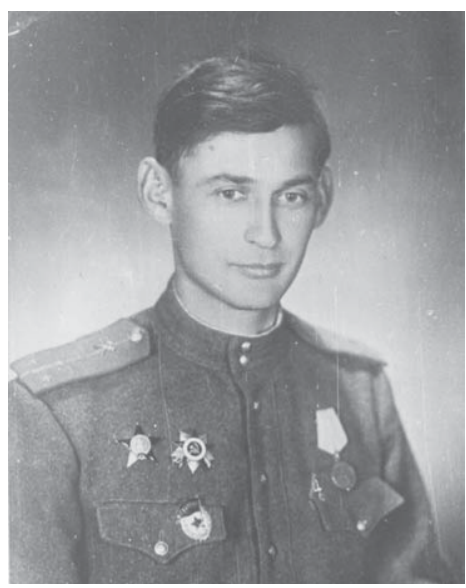

Рис. 6. В. Б. Алесковский офицер, участник боевых действий Великой Отечественной войны (1943)

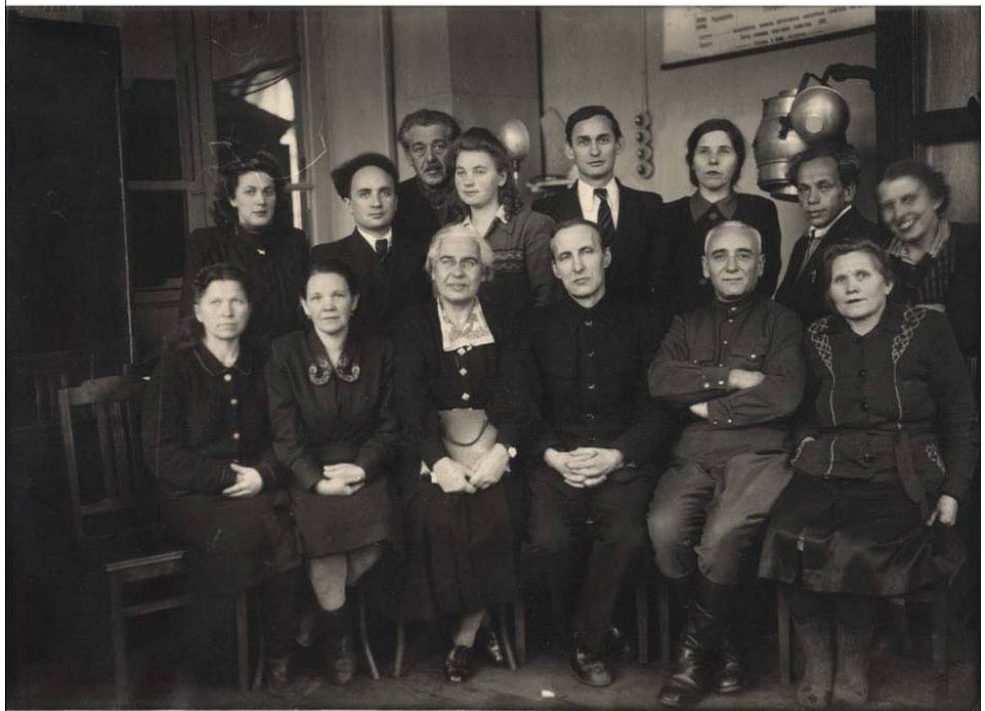

Рис.8. В.Б. Алесковский (в центре 2-ого ряда) - молодой кандидат наук на кафедре сорбционной техники Ленинградского Технологического института (1946)

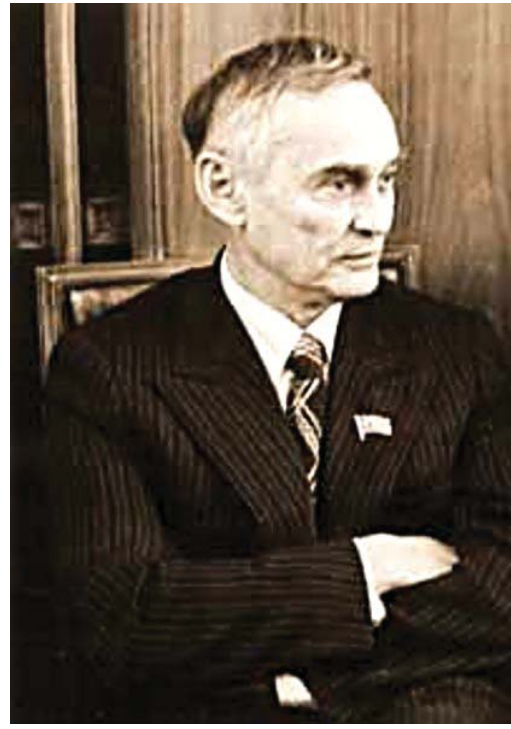

Рис. 9. Ректор ЛТИ им. Ленсовета В.Б. Алесковский в год избрания членомкорреспондентом АН СССР (1972)

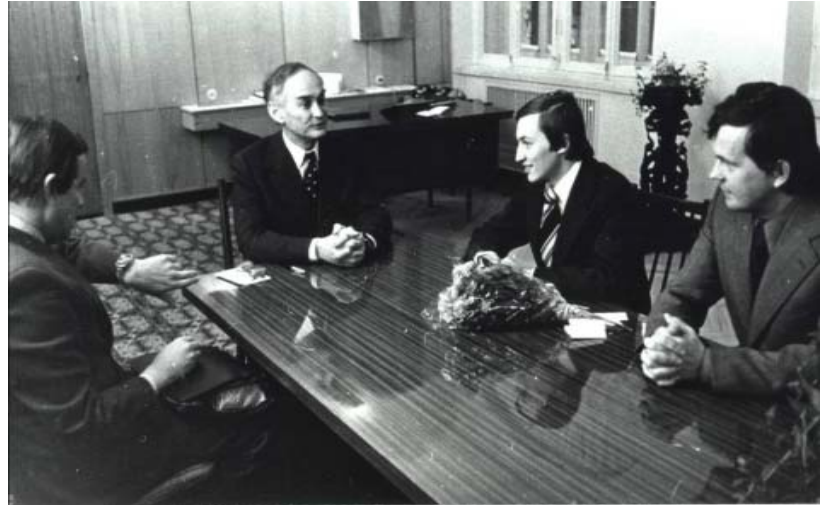

Рис.10. Ректор ЛГУ В. Б. Алесковский беседует с выпускником университета, чемпионом мира по шахматам А. Е. Карповым (1980)

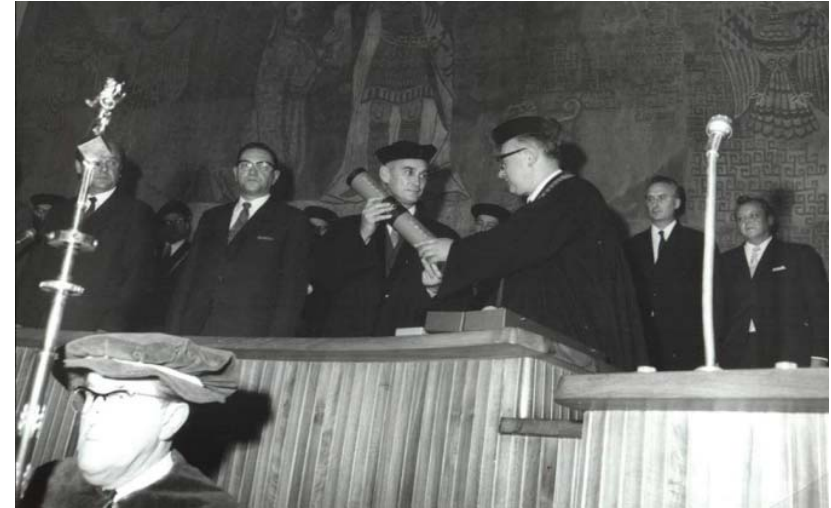

Рис. 11. Вручение профессору В. Б. Алесковскому мантии и диплома почетного профессора Пражского университета (1982) 


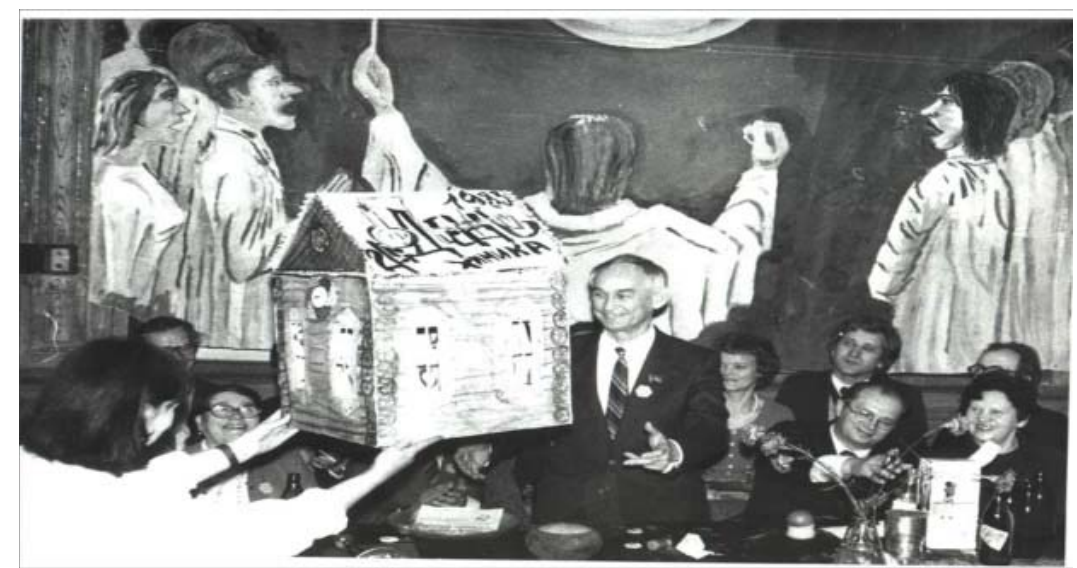

Рис. 12. Профессор В. Б. Алесковский на праздновании Дня Химика в ЛГУ

Алесковский В. Б. награжден орденами Красной звезды (1943), Отечественной войны II степени (1944), Трудового Красного Знамени (1963), Ленина (1971). Работал депутатом Верховного совета РСФСР, председателем совета ректоров вузов Ленинграда, неоднократно представлял российскую и советскую науку на зарубежных конгрессах (Канада, Великобритания, Германия). Почетный доктор и профессор технических университетов Магдебурга, Дрездена, Пражского университета. Им подготовлено свыше 30 докторов и 150 кандидатов наук.

На Международном симпозиуме НиН-2017 первые два доклада Пленарного заседания были сделаны Мякиным С. В. из СПбГТИ (ТУ) и Шиловой О. А. из ИХС им. И. В. Гребенщикова РАН (рис. 13).
Доклад Мякина С. В. был посвящен методам усовершенствования электрохромных устройств на неорганической основе. Доклад Шиловой О. А. золь-гель синтезу, исследованию и применению мультферроиков - порошков со структурой «ядрооболочка».

Интересный доклад «Эффекты интеркаляции графена с цезием в термоэлектронном преобразователе» был сделан профессором Мустафаевым А. С. (СПГУ) в соавторстве с профессорами Кагоновичем И. Д. (Принстонский университет) и Сухомлиновым В. С. (СПбГУ).

Профессор Н. М. Барбин (рис. 14) из УрФУ (г. Екатеринбург) с соавторами из УРИ ГПС МЧС России и УрГАУ традиционно представляет новые данные о термодинамическом моделировании поведения различных фуллеренов и наночастиц угле-

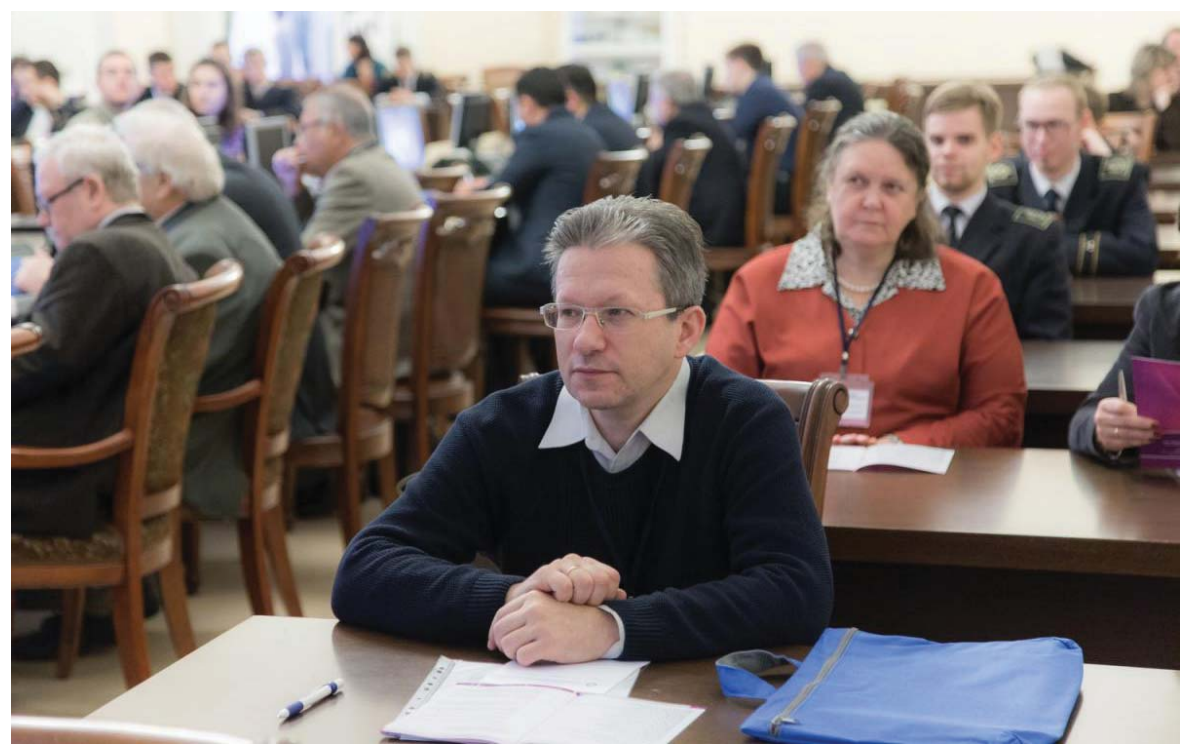

Рис. 13. На переднем плане - докладчик из СПБГТИ (ТУ) доцент Мякин С. В., за вторым столом - профессор Шилова О. А., член Оргкомитета НиН-2017 


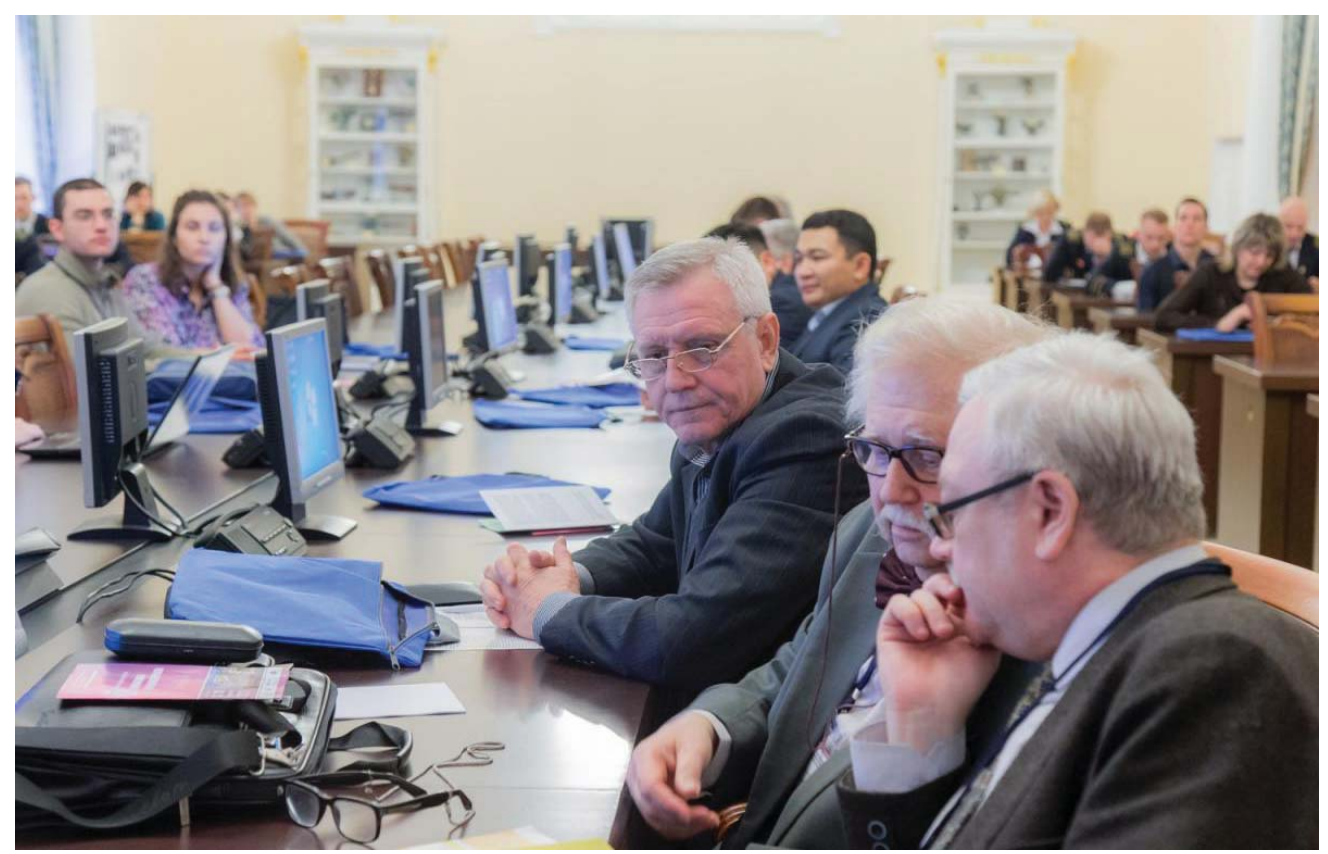

Рис. 14. На переднем плане справа-налево: профессор Барбин Н. М. (см. также рис. 3.), профессор Марголин В. И. (СПбГЭТУ «ЛЭТИ»), Седов А. И. - ФТИ им А. Ф. Иоффе РАН

рода. На НиН-2017 им был сделан пленарный доклад по моделированию нагревания фуллеренов $\mathrm{C}_{70}$ в инертной среде.

Оригинальные результаты в развитие наноуглеродной тематики были озвучены д.Х.н. Рожковой Н. Н. (НГ КарНЦ РАН) в докладе «Структурные свойства гибридных наночастиц металлграфен, полученных методом лазерной абляции в воде» по итогам совместной работы с ИБ КарНЦ РАН и Владимирским госуниверситетом (ВлГУ).

В перерывах между докладами и заседаниями симпозиума НиН-2017 участникам показывали фильм «Защита без нападения» (Центрнаучфильм, Москва, 1981). Фильм посвящен решению проблем экологии с использованием метода молекулярного наслаивания (химической сборки). Часть съемок проходила на территории кафедр химии твердых веществ ЛТИ им. Ленсовета и химии твердого тела ЛГУ, созданных по инициативе В. Б. Алесковского в 1967 и 1978 годах соответственно. В частности, в этом фильме было впервые продемонстрировано получение металлоизделий напрямую из руды, минуя традиционные переделы (плавление металла и механическую обработку твердой заготовки) металлургического производства. Некоторые дополнительные комментарии были даны в пленарном докладе профессора Сыркова А. Г., подготовленного совместно с сотрудниками Белорусского государственного технологического университета (БГТУ) и компанией IMCMontan.
В своем докладе «Проблемы постоянства состава твердых соединений по Курнакову, Веймарну, Алесковскому и данным современных нанотехнологических исследований» Сырковым А. Г. был не только проанализирован вклад В. Б. Алесковского в мировую науку, но и особенности взглядов представителей различных школ на химическую природу твердых веществ и стехиометрию последних. По мнению Н. С. Курнакова, которого придерживаются и многие современные ученые, индивидуальные химические соединения могут иметь как постоянный, так и переменный состав. Развивая взгляды Бертолле, Курнаков считал, что для твердых химических соединений превалируют соединения переменного состава («бертоллиды»), а не постоянного («дальтониды»). П. П. Веймарн возражал Курнакову: «если уже непременно надо делить соединения атомовна группы, то уже никак не бертоллиды и дальтониды ... ибо Бертолле развивал неправильные идеи» [9]. В. Б. Алесковский занял близкую по смыслу позицию: «в самом понятии “соединения переменного состава" содержится явное противоречие. Ясно, что одно и то же химическое соединение не может иметь разный химический состав» [10]. Особенность воззрений П. П. Веймарна состояла в том, что он не допускал существования соединений переменного состава, не делая исключения для адсорбционных соединений. По Алесковскому, получать индивидуальные наночастицы постоянного состава и воспроизво- 
димого строения необходимо в условиях необратимого химического синтеза $[3,4,10]$.

Среди представленных секционных докладов можно выделить работу по терморасширенному графиту на основе соединений соинтеркалирования нитрата графита (Войташ А. А., Вишневский В. Ю., Берестнева Ю. В. и др.). Это совместная работа Института физико-органической химии и углехимии им. Л. М. Литвиненко НАН Украины (г. Донецк) и Донецкого физико-технического института им А. А. Галкина.

Среди выступлений на круглом столе необходимо отметить работу СПГУ и СПбПУ по неразрушающей оценке нанохарактеристик прочности конструкционных материалов (докладчик - профессор В. В. Носов). Это выступление наряду с докладом Ю. М. Жукова (ОАО «Экситон Аналитик») по спектроскопическим методикам анализа наноструктур освещает важное для развития наноиндустрии направление по неразрущаюшим методам контроля наноматериалов. Надо отметить также весьма содержательный доклад профессора Пака В. Н. о структуре и сорбционных свойствах глинистых минералов. По мнению представителей британской компании IMC Montan, эта работа - готовое коммерческое предложение.

Второй день работы симпозиума НиН-2017 (23 ноября), проведенный в Главном здании СПГУ, включал экскурсии в церковь Горного университета, в Горный Музей (рис. 15, 16) и Центр коллек-

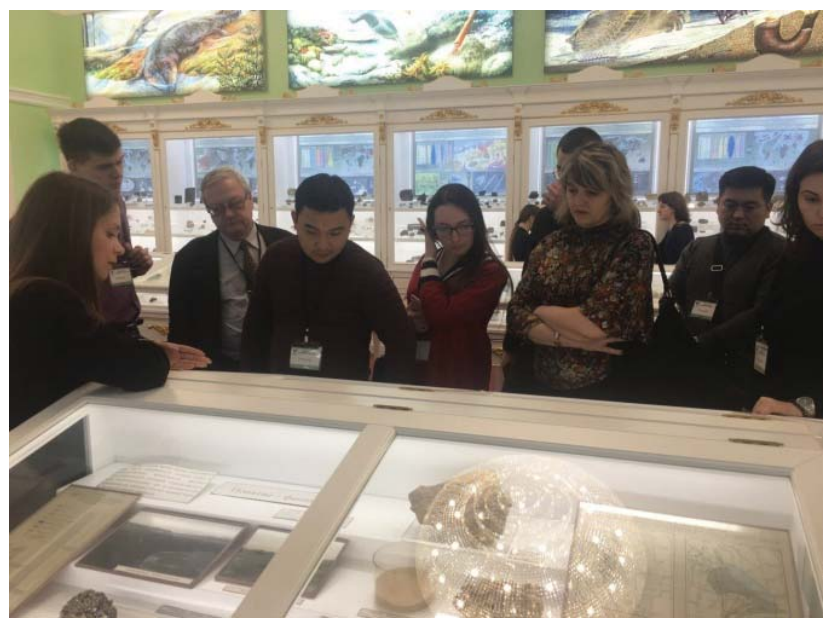

Рис. 15. Отечественные и зарубежные гости НиН-2017 осматривают экспозиции СПГУ: второй слева проф. Н. М. Барбин (УрФУ, Екатеринбург); третий слева - доктор М. Жамантаев, второй справа - главный специалист К. Атаев (Национальный республиканский центр технологического развития, Казахстан, Алматы) тивного пользования высокотехнологичным оборудованием.

Участниками НиН-2017 стали представители Университета Западной Вирджинии, Принстонского университета (США), БГТУ (Беларусь). Впервые в работе симпозиума приняла участие делегация из Казахстана (рис. 15) и представили доклады академические институты Донецка.

Российские вузы - участники НиН-2017: МГУ, НГУ, ЮФУ, Тамбовский и Пензенский государственные университеты, РГРТУ, СПГУ, СПбГЭТУ “ЛЭТИ”, СПбГТИ(ТУ), Университет ИТМО, СПбГУТ им. М. А. Бонч-Бруевича, РГПУ им. А. И. Герцена, УрФУ, УрГАУ, УрИ ГПС МЧС России, ВлГУ, СФУ, ВГТУ.

Учреждения РАН, помимо ИХС РАН и ФТИ им. А. Ф. Иоффе РАН, представляли ИМХ РАН, Институт геологии, Институт биологии КарНЦ РАН. Тренд на усиление активности сотрудников академических институтов в работе симпозиума, отмеченный ещё на НиН-2016 [5], в 2017 г. дополнительно подтверждается появлением в составе Оргкомитета НиН-2017 профессоров, работающих в системе РАН или являющихся членами НАН РБ. Новые члены Оргкомитета: член-корреспондент РАН В. В. Гусаров (ФТИ РАН, СПб), О. А. Шилова (ИХС РАН), а также член-корреспондент НАН Беларуси, Заслуженный деятель науки РБ Н. Р. Прокопчук (рис. 16, 17)

Впервые в работе симпозиума «Нанофизика и Наноматериалы» приняли участие сотрудники ме-

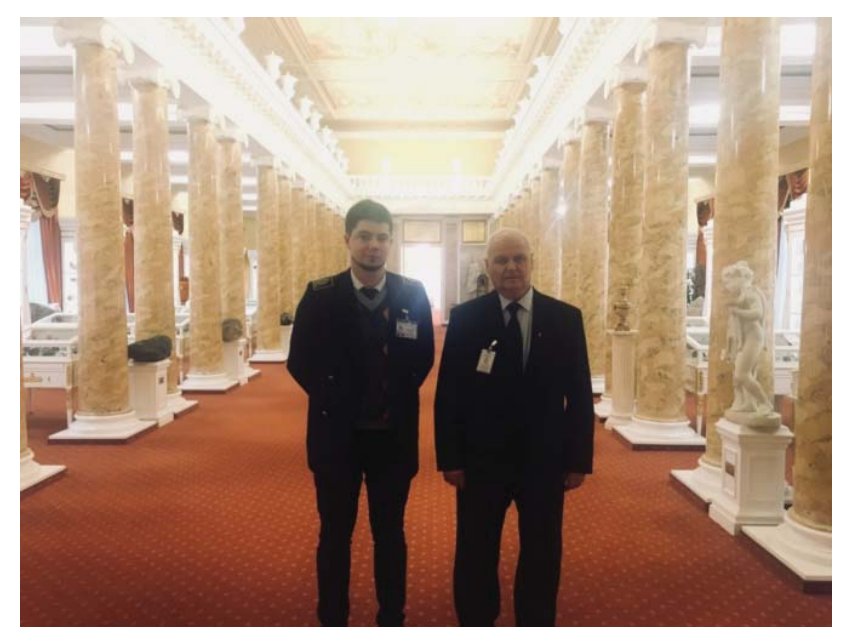

Рис. 16. Член-корреспондент НАН Беларуси Н. Р. Прокопчук (БГТУ) и аспирант М.О. Силиванов (СПГУ) в Горном музее 


\section{А. Г. СЫРКОВ}

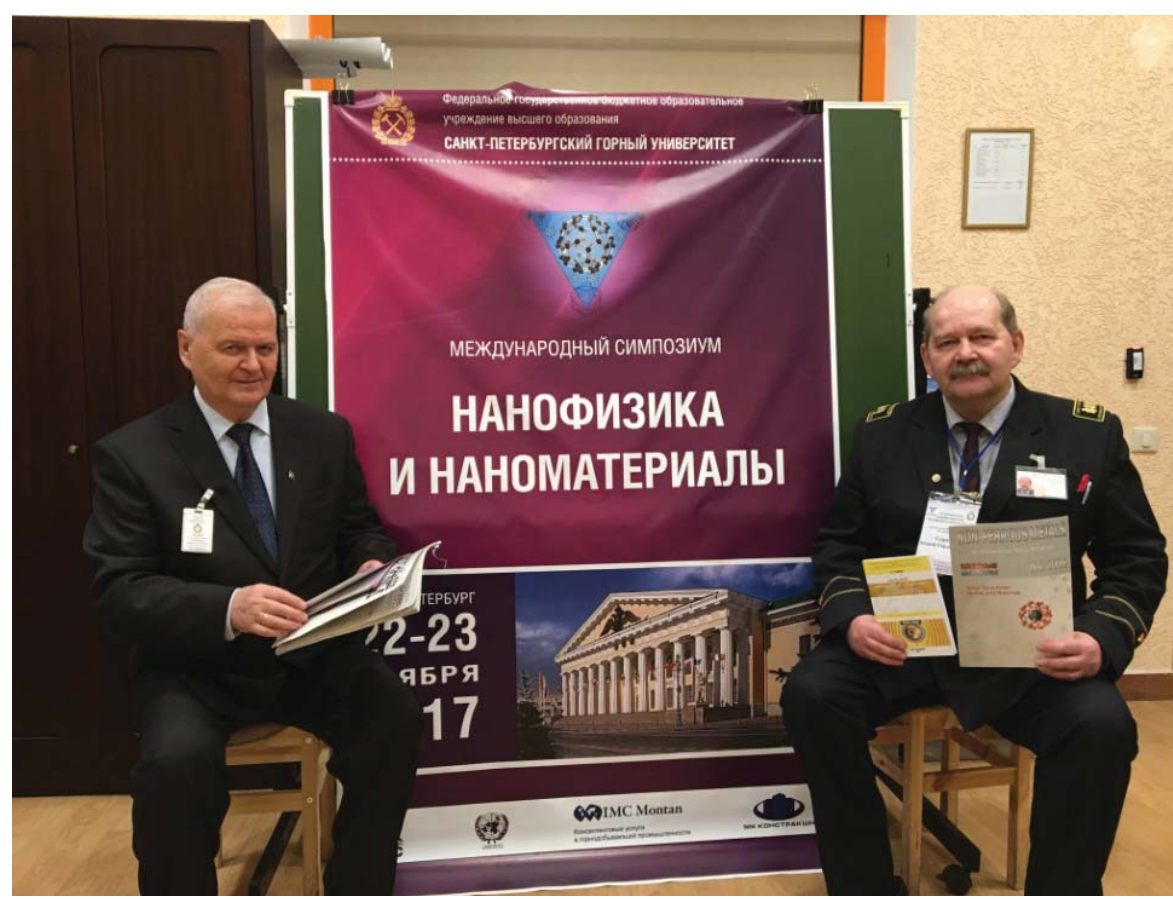

Рис. 17. Иностранный заместитель председателя Оргкомитета, член-корреспондент НАН Беларуси профессор Прокопчук Николай Романович и научный руководитель симпозиума, заместитель председателя профессор Сырков Андрей Гордианович

дицинских учреждений: Нижегородской государственной медицинской академии Минздрава РФ (с докладом) и НИИ Гриппа (в качестве слушателя).

В ходе симпозиума НиН-2017 участниками было представлено 8 пленарных докладов, 13 секционных презентаций и 12 докладов в дискуссии на круглом столе.

Консалтинговые и внедренческие компании на НиН-2017 представляли IMC Montan - главный партнер симпозиума, ОАО «Экситон Аналитик» и Национальный республиканский центр технологического развития (Казахстан).

На заключительном круглом столе симпозиума «Нанофизика и Наноматериалы» было отмечено, что проведенный научный форум выполнил поставленные задачи по обмену на высоком научном уровне актуальной информацией в области физики, химии и технологии низкоразмерных систем и привел к возникновению новых творческих и деловых контактов в сфере нанотехнологий для минерально-сырьевого комплекса.

Проведение следующего Международного симпозиума «Нанофизика и Наноматериалы», посвященного 15-летию его деятельности, намечено на 27-28 ноября 2018 г. и официально включено в число научно-технических мероприятий в СПГУ на этот год.

\section{СПИСОК ЛИТЕРАТУРЫ}

1. Третьяков Ю.Д. // Вестник РАН, 2007, № 1, c. 5-7.

2. Puurunen R.L. // J. Appl. Phys., 2005. vol.97, № 12, p. 121301.

3. Алесковский В. Б. Строение и свойства надмолекулярных (твердых) веществ. СПб: СПбГУ, 1994, $96 \mathrm{c.}$

4. Химия твердого тела. Химические проблемы создания новых материалов. СПб: СПбГУ, 2003, 315 с.

5. Сырков А. Г. // Конденсированные среды и межфазные гранищь, 2017, т. 19, № 1,с. 140-147.

6. Syrkov A. G. // Journal of Mining Institute, 2016,vol.221, pp. 730-736.

7. Synthesis, Characterization and Modeling of NanoSized Structures. / Ed. by K. Levine. New York: Nova Science Publishers, Inc., 2017, 175 p.

8. Nanoscale-Arranged Systems for Nanotechnology. I Ed. by K. Levine. New York: Nova Science Publishers, Inc., 2015, 191 p.

9. Веймарн П. П. // Записки Горного института, 1912. т. 4(2), с. 115-127.

10. Алесковский В. Б. Химия твердых веществ. М.: Высшая школа, 1978, 140 с. 


\title{
INTERNATIONALSYMPOSIUM "NANOPHYSICSANDNANOMATERIALS" IN SAINT-PETERSBURG, DEDICATED TO THE 105TH ANNIVERSARY OF THE BIRTH OF V. B. ALESKOVSKII
}

\section{(C) 2018 A. G. Syrkov}

\begin{abstract}
Information about scientific reports made at the international Symposium "Nanophysics and Nanomaterials" (Russia, Saint-Petersburg, November 2017) is provided. The contribution to the world science of the corresponding fellow of the Russian Academy of Sciences Professor V. B. Aleskovskii (1912-2006) has been analyzed. The representations of Aleskovskii in the field of stoichiometry of solids, research of his scientific school related to molecular layering and synthesis of nanomaterials are briefly considered. Reports on the problems of improving electrochromic devices on an inorganic basis, sol-gel powder synthesis with the structure of "core-shell", in the field of simulation of fullerenes heating, synthesis of metal-graphene structures, thermally expanded graphite, solid-state hydride synthesis of metals were discussed. The Symposium was attended by experts from UK, USA, Belarus, Kazakhstan, Ukraine and Russia.
\end{abstract}

DOI: https://doi.org/10.17308/kcmf.2018.20/488

Сырков Андрей Гордианович - д. т. н., професcop, Санкт-Петербургский горный университет; e-mail: syrkovandrey@spmi.ru
Andrey G. Syrkov-Dr. Sci. (Eng.), Professor, SaintPetersburg Mining University; e-mail: syrkovandrey@ spmi.ru 